\title{
Multidisciplinary Practices: Reality Or Illusion
}

W. Michael Seganish, (E-mail: wseganish@aol.com), Towson University Norma C. Holter, (E-mail: holter@towson.edu), Towson University

\begin{abstract}
A Multi-disciplinary practice is a practice or partnership formed between a lawyer and a nonlawyer, usually between a lawyer and an accountant. As the lines blur between many of the services rendered by an attorney and an accountant, the multi-disciplinary practice becomes appealing. Common ground has been found in tax matters, financial planning, elder law, and employment matters. However, many impediments must be overcome to enable this form of practice to flourish. These impediments, from both the legal and accounting profession, are discussed. Analysis of the Codes of Professional Conduct and state statutes suggests that the challenges may be difficult to overcome.
\end{abstract}

\section{Introduction}

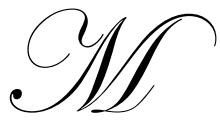

ulti-disciplinary practices (MDPs) are formed when lawyers and non-lawyers form a partnership or other recognized form of business (such as professional corporations, limited liability partnerships) in order to provide legal and non-legal services to the public. Other informal MDPs are strategic alliances formed between professionals, usually accounting and law firms, in which they engage in joint marketing and delivery of services, as well as the sharing of fees.

MDPs are a fairly recent concept in the legal profession, especially in the United States. Today, MDPs represent one of the most important changes that may eventually result in the alteration of the practice of law, as we know it today. The issue of MDPs has given rise to a seemingly endless heated debate between its advocates and opponents with few clear cut resolutions.

\section{Advocates' Position}

The advocates of MDPs argue that MDPs are in the best interest of the client, who is the single most important component to the success of any firm. Not only do MDPs promote competition but they also offer convenience to the public and assist the professional in the delivery of a variety of specialized services. For example, if an attorney handles an estate and files the appropriate probate forms, the attorney will nonetheless have to employ an accountant to prepare the appropriate fiduciary returns for tax purposes. Today, clients are looking for fast and efficient delivery of professional services. MDPs are the one feasible alternative to a society that operates in a real time environment and needs quick answers to complicated issues which require the expertise of different professionals.

\section{Opponents' Position}

Many attorneys feel that MDPs impair the core values of the profession because attorneys are subject to higher ethical standards through their Code of Professional Responsibility. A majority of the members of the bar, as well as the American Bar Association, agree. Conflict arises between the different ethical standards of professionals in other fields. An essential issue when considering mplementing MDPs is whether non-attorneys should be

Readers with comments of questions are encouraged to contact the authors via email subjected to higher ethical standards or whether attorneys should compromise their core principles as espoused by 
the Rules of Professional Conduct. Since the answer to the dilemma is extremely complex, the obvious resolution, in the eyes of the opponents to MDPs is to ban the formation of MDPs.

\section{A Brief History}

\section{United States}

MDPs are not allowed in most jurisdictions in the United States. The Model Rules of Professional Conduct are the source of the ethical standards of all lawyers. These Model Rules forbid, under Rule 5.4, the splitting of fees between lawyers and non-lawyers. This Rule exists primarily to protect the public from a lawyer who may hire a marketing person to solicit business and pay a commission for this service.

The AICPA Code of Professional Conduct (Rule 503) prohibits a member in public practice from accepting a commission for referring a product or service to any client for which the CPA performs an audit, review, compilation when it will be used by third parties, or an examination of prospective financial information. Any CPA not prohibited by that rule and who receives a commission for referring a product or service, must disclose the fact that they will be receiving the commission or referral fee to the client.

The District of Columbia is currently the only jurisdiction in the United States that has modified its rules in order to allow MDPs in restricted situations. MDPs are allowed only if their sole purpose is to provide legal services. If any non-legal services are to be rendered, such as auditing or tax services by an accountant, then the MDP is forbidden. All managers, including accountants, participating in the MDP, as well as those individuals with a financial interest in the MDP, must adhere to the strict Rules of Professional Conduct. Furthermore, the lawyers involved in the management of the firm are responsible for non-lawyer participants in the firm as if they are lawyers.

The AICPA Code of Professional Conduct maintains the same standards: the CPA partner is held responsible for all non-CPA members' compliance with the AICPA Code of Conduct. If a non-CPA partner violates the Code, the member is held accountable. In addition, if the MDP were to perform attest services, the majority of the financial interests must be owned by CPAs.

The first firm said to organize towards a MDP was McKee, Nelson, Ernst \& Young. Although the jurisdiction permits a law firm to use a trade name, the use of the name Ernst \& Young may be deceiving to prospective clients who relate Ernst \& Young with accounting rather than legal services, so it was organized as McKee Nelson, LLP (limited liability partnership). Ernst \& Young is opening a second affiliate law office, operated under the name McKee Nelson, in New York City to compete with other Wall Street firms. ${ }^{i}$ These firms are actually strategic alliances whereby the law firm, owned by lawyers, shares technology, and infrastructure with Ernst \& Young, the accountants.

The Bar Association of the Bar for the City of New York advocates the formation of MDPs "under a regime that requires MDPs to respect and preserve the core values of the legal profession". ii This is virtually impossible. The other states, each under its own jurisdiction, oppose the formation of MDPs in any way, shape, or form. The main argument remains that MDPs will not serve the best interest of the client because the fiduciary duty and other duties a lawyer vows to the client are compromised.

\section{Europe}

MDPs have been allowed in European countries since the early 1990s, and are subject to less restrictions than in the United States. Accounting firms worldwide are the largest employer of lawyers in the world. The largest and most prestigious accounting firms in Europe have hired thousands of lawyers for their firms to provide both legal and non-legal services. (KPMG and Ernst \& Young employ more lawyers than the biggest law firms.) ${ }^{\text {iii }}$ European law allows non-lawyers to offer legal advice as long as they do not misrepresent their credentials. This would be considered the unauthorized practice of law in the United States. Non-lawyers in Europe may also provide transactional services, but may not go to Court to represent a client. 


\section{Views \& Rulings on MDPs by Governing Lawyer Association}

The American Bar Association (ABA), which is an association of lawyers nationwide, formed a Commission on Multi-Disciplinary Practices in August 1998 to study whether or not MDPs should be permitted in the United States. The Commission produced a report in the summer of 1999, with the conclusion that the Rules of Professional Conduct "should not permit existing rules to unnecessarily inhibit the development of new structures for the more effective delivery of services and better access to the legal system". iv In other words, the Commission argued that the Rules of Professional Conduct should be interpreted or altered where possible in order to allow MDPs to meet the needs of society.

The MDP Commission reported that MDPs may be in the best interests of the client because they tend to reduce and/or eliminate communication problems between various professionals working on a multidisciplinary task for a client. MDPs will help ensure that tasks are completed in a more timely fashion due to the more efficient handling of legal and non-legal matters without delays to obtain assistance of other professionals because they are in the same firm. Thus, the Commission argues that MDPs will be beneficial both to the public and to the professional and, therefore, should be allowed in the United States in order to provide the best services possible to serve the public interest.

The American Bar Association, after reviewing the recommendations of the MDP Commission that it appointed, rejected the Commission's conclusions that MDPs should be encouraged. The ABA continued the restriction on lawyers' ability to enter into a partnership agreement with non-lawyers; of not permitting lawyers to share fees with non-lawyers, and prohibiting non-lawyers to own or control entities that practice law as being inconsistent with the lawyers' Rules of Professional Conduct. The ABA was apprehensive that MDPs would cause the legal profession to become a business, a premise that is inconsistent with the duty of a lawyer to zealously represent a client.

Since the legal profession in the United States is governed by fifty-one separate jurisdictions, the recommendations of the ABA on the issue of MDPs is merely that, a recommendation. The States have the right to decide whether or not to abide by the ABA recommendation. To date, the only jurisdiction that has dissented from the recommendation of the ABA is the District of Columbia and it did so by modifying its Code of Professional Conduct.

\section{Impediments to MDPs}

The American Bar Association, in taking a position against MDPs in the United States, cites four major impediments to MDPs between attorneys and accountants. The four arguments include: 1) impairment of professional judgment; (2) protection of confidential information; (3) loyalty to client through avoidance of conflict of interest; and (4) independence of lawyers. Each of these arguments will be discussed from the attorney's and accountant's perspective.

\section{Impairment of Professional Judgment}

\section{Advocacy vs. Objectivity}

Attorneys are advocates and must remain subjective in the representation of clients. Attorneys have an obligation to represent the client's interest and to act in the best interest of clients. On the contrary, accountants, as auditors, must remain objective. Auditors must be impartial and maintain professional skepticism in order to express an opinion as an independent outsider to the company.

However, in a divorce proceeding, the attorney and the accountant, who may be solicited for help with valuation of assets and taxation matters, are both advocates of the client. Depending on the services rendered, conflicting duties of accountants and attorneys could impair the judgment of both parties. 


\section{Protection of Confidential Information}

The attorney/client privilege is a Common Law fundamental right that upholds one of the core values of the legal profession. Confidentiality is at the center of every attorney/client relationship, which allows full disclosure of all relevant facts in a case. Without the promise of confidentiality, clients may be inclined to be dishonest, or at least less than fully candid, which could hinder the services the attorney can provide for that client.

Although accountants have a common law duty of confidentiality to clients, it is not an absolute privilege as with the attorney/client privilege. Not all states (Eighteen states and Puerto Rico have adopted a CPA-client privileged communication statute). ${ }^{\mathrm{v}}$ Have the accountant/client privilege and none exists in the Federal area. For example, in a tax matter, an accountant can be called to testify. Accountants may be subpoenaed to court because of the limited nature of their confidentiality agreements.

The AICPA Code of Professional Conduct (Rule 301) states that a CPA in public practice cannot disclose any confidential client information without the specific consent of the client. The same rationale applies. In order for the CPA to have the client's trust, the client must understand that the matters discussed will be held in confidence.

A partnership of accountants and lawyers may result in the disclosure of confidential information from the lawyer to the accountant, who is held to a lesser standard of confidentiality. The sharing of information with nonlawyers who do not have legal confidentiality privileges destroys the attorney/client privilege unless the accountant is hired by the attorney. The argument of the ABA is that in order to preserve the nature of the attorney/client privilege without sacrificing the strict confidentiality agreement, either MDPs must be prohibited or non-lawyers must be subjected to a higher standard of confidentiality and protected from producing information.

\section{Avoidance of Conflict of Interest}

In a MDP, lawyers may be pressured by non-lawyers to act counter to the best interest of the client, or may feel conflicted to protect the interests of the partnership as well as the client. As a professional in a principal-agent relationship, the attorney has a fiduciary duty to act in the best interests of the client, which means among other things, avoiding a conflict of interest or even the appearance of a conflict of interest. Attorneys have the duty to serve the public interest, not self-interest. When lawyers and non-lawyers engage in profit sharing, then there may be pressure to serve the public but with a focus on self-interest. For example, in providing legal advice to a client, the lawyer who has an accountant as a partner may be inclined to refer the client to the accountant so as to produce more revenues. Although the referral is in the interest of the partnership, it may not serve the best interest of the client, who relies on information provided by the attorney.

Integrity, independence, and objectivity are bedrocks of the ethical foundation for the practice of accountancy. Rule 102 of the AICPA Code of Professional Conduct states: "In the performance of any professional service, a CPA shall maintain objectivity and integrity, shall be free of conflicts of interest, and shall not knowingly misrepresent facts or subordinate his or her judgment to others". ${ }^{\text {vi }}$ The legal and accounting professions expect and profess the same degree of integrity. In addition, the AICPA maintains very tight limitations on situations where a CPA may accept a referral fee or commission, as mentioned previously.

\section{Independence of Lawyers}

One of the most prevalent fears of the ABA is the fact that a non-lawyer partner of a MDP might exercise undue influence over the independence of a lawyer in the course of the representation of a client. As one of the core values of the legal profession, independence is essential to maintaining the power and integrity of an attorney. Unfortunately, in forming a partnership with a non-lawyer, some of the power shifts to the partner and "as soon as the power rests with non-lawyers not trained in, not dedicated to and not subject to discipline for our ethical principles, you will see the independence of the profession fall away". vii 


\section{Review of Current Rules}

"A central purpose of the codes of legal ethics throughout the history of the United States has been to preserve and protect the exercise of a lawyer's independent professional judgment in service to the client". viii In the United States, lawyers are effectively barred from openly practicing law and accountancy through a single organization by several existing Rules of Professional Conduct:

1. Interprofessional fee splitting and partnerships (Rule 5.4)

2. Unauthorized practice of law (Rule 5.5) the giving of legal advice by a non-lawyer

3. Representing clients when any firm lawyer has a conflict of interest (Rules 1.7,1.9, 1.10) or when representation would be affected by responsibility to third persons.

4. A lawyer must be an advocate for the client (Rule 3.1)

5. A lawyer cannot represent a client if he is a witness. (Rule 3.7)

6. Confidentiality of information (Rule 1.6)

If, in forming a MDP, lawyers violate these rules, they may suffer serious consequences, including the loss or suspension of a law license, disqualification from client representation, injunction, or criminal penalties.

\section{Independence of Accountants/CPAs}

The independence of the CPA/auditor is sacrosanct. Independence is required for audits, reviews, and other attest functions. The CPA/auditor must be independent in fact and avoid any circumstances that may lead to a perception of impairment of independence. Generally, independence is impaired when an auditor has a mutual or conflicting interest with the audit client; audits the auditor's own work; functions as an employee or member of management of the audit client; or acts as an advocate of the audit client. ${ }^{\text {ix }}$ Independence requires that the auditor be independent of the interests of the client and follow the common law duty to protect the interests of public shareholders.

One of the reasons the capital markets operate so efficiently in the United States is because publicly traded companies are required to have an independent annual audit. There are tremendous pressures on corporate management to meet analysts" expectations of earnings and this pressure can translate into management "stretching" or creatively interpreting accounting principles. The audit is performed to provide an independent opinion on the financial statements as they conform to generally accepted accounting principles.

The SEC, whose rules impact CPAs auditing publicly traded companies, agrees there is a fundamental conflict between the role of the independent auditor and that of an attorney. The SEC holds that independence is impaired when legal services are provided by an audit firm or its affiliate. For these reasons, the SEC supports the position of the ABA that "(no) single entity should be allowed to provide legal and audit services to the same client". The continuous growth of consulting and other non-audit services by the national CPA firms has already caused concern within the SEC about impairment of auditor independence. A securities litigation lawyer who has prosecuted fraud cases, and has been privileged to review internal corporate documents sealed from the public, has said, “...We have seen repeated instances where auditors are unable to maintain independence from their clients. Not infrequently, the lack of independence arises most directly from the fact that the auditing firm has substantial consulting relationships with the client..." ${ }^{\text {’i }}$ Unfortunately, the recent disaster of Enron will stoke these concerns.

Currently, the Rules of the AICPA Code of Professional Conduct that prohibit the formation of a MDP are:

1. Independence (Rule 101)

2. $\quad$ Contingent fees (Rule 302)

3. Commissions and referral fees (Rule 503)

4. $\quad$ Form of Organization (Rule 505)

However, Rule 505-2 states that a member in public practice may own an interest in a separate business that performs for clients the professional services of accounting, tax, personal financial planning, and litigation sup- 
port services, but the entity, the owners, and employees must all comply with the provisions of the Code of Professional Conduct. If by forming a MDP, accountants violate these rules, they could face liability to third parties, sanctions by the AICPA and the State society of CPAs, suspension or loss of their license. The SEC rules would prohibit the MDP and the accountant could face sanctions and violation of securities laws.

\section{Changes Necessary to Facilitate MDPs}

In order to facilitate MDPs, the Rules of Professional Conduct for both attorneys and accountants require modification to allow partnerships with other professionals and the sharing of fees. There is correlation between the Codes for attorneys and accountants in terms of the ethical principles and ideals of integrity, confidentiality, and conflict of interest. If a federal regulatory board would be initiated to regulate such entities as MDPs, the problem of the various State Bar Associations and State Accountancy Boards would still exist. This patchwork of rules and regulations are a formidable obstacle. The AICPA has expressed willingness to explore the possibility of MDPs but the American Bar Association has not been receptive to the idea.

Many of the problems identified with the MDPs are faced by members of both professions today, for example, avoidance of conflict of interest, maintaining integrity, and impairment of independence. The success of the Codes of Professional Conduct relies on the individual practitioners. Instead of approaching this issue from an entity viewpoint, both professions should step back and "look at the trees".

The attorney-client privilege as it relates to confidentiality should be extended to the other professional partners in a MDP partnership. This privilege is currently extended to other professionals if they are hired by an attorney. Partners of a MDP would be held to the standards of both professions because the Codes of Professional Conduct would be integrated. Who would be entrusted with enforcement of these Rules would have to be determined.

The insurance industry would have to establish standards and policies that would extend malpractice insurance and liability coverage to all partners.

Perhaps the best coalition of attorneys and accountants would be on a smaller scale than the Big Five accounting firms and the largest legal firms, in firms that provide services such as personal financial planning, estate planning, tax planning, and valuation of assets. These are areas where the legal and accounting professions complement each other. Most major movements have begun with small steps.

\section{Future of MDPs}

MDPs are commonplace around the world. It is inevitable that MDPs will begin to emerge in the United States in the near future because of the complexity of transactions in this global marketplace. The marketplace will demand quicker response, which can be achieved through coordination of services. The lines between legal and non-legal services are blurring. If the Multidisciplinary practice between a lawyer and an accountant is indeed an illusion in the United States, then perhaps strategic alliances such as Ernst \& Young and McKee Nelson will represent the future course which "MDPs" will take.

Above all else, the ethical foundations of both professions must be maintained.

\section{References}

1. AAA Financial Accounting Standards Committee. "SEC Auditor Independence Requirements." Accounting Horizons, 15, 4. December 2001.

2. AccountingWEB, Inc. "E \& Y Goes Where No Big Five Firm Has Gone." Indianapolis, IN. http://www.accountingweb.com/cgi-bin/item.cgi?id=48208.

3. AccountingWEB, US. "Multi-Disciplinary Practices-Reality...or Only a Dream?" Indianapolis, IN. http://www.accountingweb.com/cgi-bin/item.cgi?id=48338 
4. AICPA. Code of Professional Conduct. http://www.aicpa.org

5. American Bar Association. Model Rules of Professional Conduct. Washington, D.C. http://www.aba.net.org

6. "Background Paper on Multidisciplinary Practice: Issues and Developments." Presented by the Commission on Multidisciplinary Practice to the ABA House of Delegates. January 1999.

7. Bar Leader. "Report of the ABA Commission on Multidisciplinary Practice." Summer 1999.

8. Bekman,Paul D. "MDP - Law Firm of Tomorrow?" Bar Bulletin: Maryland State Bar Association Newsletter. 15 March 2000.

9. $\quad$ Elliott, Robert K. "Who Are We As A Profession - and What Must We Become? Journal of Accountancy. February 2000.

10. Eveleth, Janet Stidman. "ABA Rejects MDP Concept: MSBA to Consider Limited MDP Approach.” Bar Bulletin: Maryland State Bar Association Newsletter. 15 August 2000.

11. Eveleth, Janet Stidman. "MDPs: One Stop Shop Law Firms???” Bar Bulletin: Maryland State Bar Association Newsletter. 15 July 2000.

12. Guy, Dan M., Alderman, C. Wayne \& Winters, Alan J. Auditing, $5^{\text {th }}$ edition. Fort Worth, Texas: The Dryden Press. 1999.

13. Moser, M. Peter. "The Argument for Change." Maryland State Bar Association Journal. Summer 1999.

14. Myers, Randy. "Lawyers and CPAs: How the Landscape is Changing." Journal of Accountancy._February 2000.

15. New Jersey Bar Association. "An Overview of Multidisciplinary Practice and its Implications for Lawyers and Consumers of Legal Services.” Mid-Atlantic Bar Conference, October 14-16, 1999. Annapolis, Md.

16. New York State Bar Association. "Report of Special Committee on Multidisciplinary Practice and the Legal Profession.” January 8, 1999.

17. Thompson, Ray, and Letcher, Jr. George E. Accounting and Auditing Current Developments. "A and A by George and Ray." PICPA Foundation for Education and Research. Pennsylvania: 2001.

18. Wilber, James. “ABA Stakes Out its Position on Multidisciplinary Practice.” Altman Weil, Inc. 1999.

\section{Endnotes}

i AccountingWEB, Inc. 2001, May 30. E\&Y Goes Where No Big Five Firm Has Gone. Indianapolis, IN. Retrieved November 16, 2001 from the World Wide Web: http://www.accountingweb.com/cgi-bin/item.cgi?id=48208

${ }^{i i}$ New Jersey Bar Association. An Overview of Multidisciplinary Practice and its Implications for Lawyers and Consumers of Legal Services. Mid-Atlantic Bar Conference, October 14-16, 1999. Annapolis, Md., p 4.

iii AccountingWEB US. 2001, May 31. Multi-Disciplinary Practices - Reality...or Only a Dream? Indianapolis, IN. Retrieved June 6, 2001 from the World Wide Web: http://www.accountingweb.com/cgi-bin/item.cgi?id=48338

${ }^{\text {iv }}$ Bar Leader. Report of the American Bar Association Commission on Multidisciplinary Practice. Summer, 1999. p 1.

v Guy, Dan M., Alderman, C. Wayne, \& Winters, Alan. J. (1999). Auditing. $5^{\text {th }}$ edition. Fort Worth, Texas: The Dryden Press.

${ }^{v i}$ AICPA. AICPA Code of Professional Conduct. Retrieved December 8, 2001 from the World Wide Web: http://www.aicpa.org

${ }^{v i i}$ New York State Bar Association. Report of Special Committee on Multidisciplinary Practice and the Legal Profession. Report to House of Delegates. February 1999. p 22.

viii New York State Bar Assn. Report, 24.

ix AAA Financial Accounting Standards Committee. (December 2001). SEC Auditor Independence Requirements. Accounting Horizons, 15,4, 373-386.

x Thompson, Ray, and Letcher, Jr., George E. (2001). Accounting and Auditing Current Developments. Pennsylvania: A and A by George and Ray, PICPA Foundation for Education and Research.

xi Thompson, 54. 
